\title{
Substitution and optimization of Nigerian white beniseed (Sesamum indicum L.) cake for soybean meal in Cobb broiler diets
}

\author{
Victor Okoro ${ }^{1 *}$, Simon Akwukwuegbu², Christian Mbajiorgu ${ }^{1}$, and George Anyanwu ${ }^{2}$
}

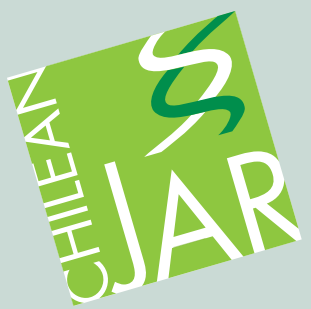

\section{ABSTRACT}

Due to competition between humans, industry and livestock for crop usage, there is need to identify alternative plant protein sources readily available and inexpensive. Beniseed (Sesamum indicum L.) cake is considered to replace soybean (Glycine max [L.] Merr.) meal as plant protein source for animal feed. This study was conducted to evaluate substitution effects of Nigerian white beniseed cake (BSC) for soybean cake (SBM) in diets of broilers, and determine optimum substitution levels. Replacement levels of BSC for SBM in diets were $0 \%, 25 \%, 75 \%$, and $100 \%$. A 56-d feeding trial was conducted on 264-d old unsexed Cobb broilers, randomly assigned to four treatment groups of 66 birds each, with three replicates of 22 birds each in a completely randomized design. A quadratic type optimization function was used to determine optimum BSC levels that significantly affected growth, carcass and blood indices. Diets $100 \%$ BSC had the least body weight at 28 $\mathrm{d}$, final body weight, average daily feed intake (ADFI), and carcass weight $(\mathrm{P}<0.05)$. Diets with $25 \%, 75 \%$ and $100 \%$ BSC had higher efficiency factor, abdominal fats and white blood corpuscles than $0 \%$ substitution diet $(\mathrm{P}<$ $0.05)$. Diet $25 \%$ BSC showed significantly higher dressing percentage $(\mathrm{P}<0.05)$, and diet $0 \%$ BSC had higher serum protein and urea compared to the other diets. The quadratic function indicated that ADFI was significantly optimized at $25 \% \mathrm{BSC}+75 \% \mathrm{SBM}$, with $\mathrm{R}^{2}=0.992$ and $\mathrm{P}$-value 0.051 . The threshold of $25 \%$ to $75 \%$ substitution levels of BSC can replace SBM in the diets of Cobb broilers without detrimental effects.

Key words: Carcass characteristics, European performance efficiency factor, feed conversion ratio, Glycine max, hematological indices, quadratic model.

${ }^{1}$ University of South Africa, Department of Agriculture and Animal Health, Florida 1710, Republic of South Africa.

"Corresponding author (melavicong@gmail.com).

${ }^{2}$ Federal University of Technology, Department of Animal Science and Technology, 1526, Owerri, Nigeria.

Received: 25 May 2017

Accepted: 6 September 2017.

doi:10.4067/S0718-58392017000400365

\section{INTRODUCTION}

Soybean (Glycine max [L.] Merr.) meal (SBM) generally constitute a major plant protein ingredient in most dietary feedstuffs fed to broiler chickens, while maize constitute the main energy source, which contribute to the fast energy/protein needs of the birds for rapid growth. Mengesha (2012) reported that energy and protein sources of feeds contribute more than $90 \%$ total cost for poultry feeds. Due to constant competition between human and industrial usage of these plants sources for food, there is need to identify alternative plant energy and protein sources that are readily available and inexpensive, to meet the demand of feed millers, as well as be of great value to chicken producers. According to Mahmoud et al. (2015) the competition for the available feed ingredients between humans, industrial and livestock usage, had resulted in making plant protein sources scarce and very expensive, resulting in looking at alternatives such as beniseed (Sesamum indicum L.) cake and beniseed hull. Feed stuff from agro-industrial by products such as beniseed cake (BSC) has been identified as a potential alternative protein feed stuff for animal production (Rao et al., 2008).

BSC is obtained after toasted beniseed is passed through an oil expeller. As the toasted beniseed passes through the machine, the expeller grinds and crushes it, with the pressure rupturing the oil cells in the raw material and presses the oil out through the perforations in the casing, and is collected in a thorough underneath. The residue after oil extraction is the cake and in terms of quality, the best brands of beniseed oil are comparable to olive oil.

Beniseed or sesame seeds are available in three major varieties based on husk colors: white sesame, black sesame, and golden sesame. The golden sesame is also called "brown sesame" or "yellow sesame" and their nutritional value is basically the same, but their flavor, color and other characteristics are slightly different (Langham, 2007). The white sesame is commonly used in sesame oil production in Nigeria because of its clear and bright color over oils from the other types, hence its cake being readily available and the seed generally cultivated.

Several authors had reported the effects of Nigerian white beniseed cake on poultry. Yakubu and Alfred (2014) reported the effect of whole toasted white sesame seed meal used as source of methionine in finisher broilers, while Diarra and Usman (2008) and Agbulu et al. (2010) reported the effects of soaked beniseed seed meal and full beniseed meal in supplementing synthetic methionine in laying hens and broilers respectively. Generally, a number of 
authors had reported on the effects of BSC on broilers or layers (Tangtaweewipat and Cheva-Isarakul, 1993; Mamputu and Buhr, 1995; Farran et al., 2000; Yamauchi et al., 2006; Rao et al., 2008; Mahmoud et al., 2015) . However, there is paucity of information on the use of Nigerian white beniseed cake as a substitute for soybean meal in broiler diets, as well as its optimized replacement levels.

This study therefore was aimed at evaluating the effects of substituting Nigerian white beniseed cake for soybean meal as a sole plant protein source in Cobb broiler diets; its effects on growth performance, carcass characteristics, hematological and biochemical indices; as well as identifying their optimal substitution levels on growth, carcass and blood indices of Cobb broilers using quadratic type model.

\section{MATERIALS AND METHODS}

\section{Ethics approval and study location}

This research was carried out at the poultry unit of the Teaching and Research Farm (4 ${ }^{\circ} 04^{\prime}-6^{\circ} 03^{\prime} \mathrm{N}, 6^{\circ} 15^{\prime}-8^{\circ} 15^{\prime}$ W), Federal University of Technology Owerri, Imo State, Nigeria, after securing ethical approval from the Ethics Committee of the School of Agriculture and Agricultural Technology of the University (2013/06/29/B). The locality has a mean annual rainfall of $2500 \mathrm{~mm}, 26.5$ to $34.5{ }^{\circ} \mathrm{C}$, and $70 \%$ to $80 \% \mathrm{RH}$.

\section{Sources and processing of the test materials}

The major source of the test material, white beniseed, was from College of Education, Oju, Agricultural Education Farm; while the minor source was from commercial dealers in Oju market, both in Benue State, Nigeria. The middle belt and the savannah ecological zones of Nigeria, especially Taraba, Kano, Jigawa, Nassarawa and Kebbi States are notable for the cultivation of beniseed. Soybean meal (SBM), yellow maize (Zea mays L.), and other ingredients were procured from a reputable dealer in Owerri, Nigeria.

The beniseed was processed in a commercial company located in Makurdi, Benue State, Nigeria, where an oil expeller machine similar to the type described earlier was used. Processing involved initial toasting of seeds for 10 min using a cylindrical pan to agitate the oil in the seeds, and thereafter the hot beniseed is transferred to the conical portion of the expeller; operated electrically to grind, press and release the oil through the right side of the perforated barrel while the beniseed cake (BSC) is expelled on the left side of the barrel. The operation lasts less than 30 min, depending on the quantity of BSC to be processed. Approximately $130 \mathrm{~kg}$ beniseed were processed for the starter phase yielding $70 \mathrm{~kg}$ BSC and $60 \mathrm{~L}$ oil, while $186 \mathrm{~kg}$ beniseed was processed for the finisher phase yielding 87 $\mathrm{kg}$ BSC and $99 \mathrm{~L}$ oil, respectively.

\section{Chemical analysis of test materials}

Samples of BSC and SBM were analyzed for proximate composition in the Laboratory of the Department of Animal
Science and Technology, Federal University of Technology, Owerri, using standard methods outlined by AOAC (1995). The moisture, crude protein, ether extract, crude fiber, ash and $\mathrm{N}$ free extract (NFE) contents were determined (Table 1).

\section{Management of experimental birds and design}

Two hundred and sixty four d-old unsexed Cobb broiler chicks procured from a reputable hatchery in Owerri were used for the study. The chicks were brooded for the first week and fed commercial broiler starter diet during this period. Thereafter, the broiler chicks were randomly assigned to the four dietary treatments with 66 birds per treatment in a completely randomized design (CRD), and each treatment group replicated thrice, comprising of 22 birds per replicate, housed in pens measuring $2 \mathrm{~m} \times 4 \mathrm{~m}$ on deeper litter (Table 2).

The experimental starter diets were fed from day 8 to day 28, while the experimental finisher diets were fed from day 29 to day 56, both provided with water ad libitum throughout the experiment. The nutrient and calculated chemical compositions of the starter and finisher diets are shown in Table 3. The birds were routinely vaccinated as described by Oluyemi and Roberts (2000). Electric bulbs and heaters were provided within the first $7 \mathrm{~d}$ of brooding, after which the nylon cover used to wrap around the brooder house in order to conserve heat during brooding was removed together with the heaters; and natural day light and ventilation allowed from then till the end of the feeding trial period.

\section{Parameters measured}

Parameters measured were initial body weight (IBW), body weight at $28 \mathrm{~d}$ (BW28), final body weight at $56 \mathrm{~d}$ (FBW), average daily weight gain (ADWG), average daily feed intake (ADFI), feed conversion ratio (FCR), and mortality.

Table 1. Proximate composition of beniseed cake and soybean meal.

\begin{tabular}{lcc}
\hline Nutrients $(\%)$ & Benniseed cake (BSC) & Soybean meal (SBM) \\
\hline Dry matter & 96.12 & 89.92 \\
Moisture & 3.87 & 10.18 \\
Crude protein & 47.12 & 50.18 \\
Ether extract & 14.25 & 3.93 \\
Ash & 6.20 & 5.25 \\
Crude fiber & 6.50 & 6.86 \\
Nitrogen free extract & 22.06 & 23.60 \\
\hline
\end{tabular}

Table 2. Dietary treatments.

\begin{tabular}{|c|c|c|c|c|c|c|}
\hline \multirow[b]{2}{*}{ Treatments } & \multirow{2}{*}{$\begin{array}{c}\text { Soybean } \\
\text { meal }\end{array}$} & \multirow{2}{*}{$\begin{array}{c}\text { Beniseed } \\
\text { cake }\end{array}$} & \multicolumn{2}{|c|}{ Starter diets } & \multicolumn{2}{|c|}{ Finisher diets } \\
\hline & & & SBM & $\mathrm{BSC}$ & SBM & BSC \\
\hline & 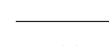 & 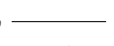 & 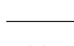 & $-\mathrm{kg}$ & $\mathrm{kg}^{-1}$ & 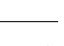 \\
\hline 1 & 100 & 0 & 30 & 0 & 25 & 0 \\
\hline 2 & 75 & 25 & 20 & 10 & 15 & 10 \\
\hline 3 & 25 & 75 & 10 & 20 & 10 & 15 \\
\hline 4 & 100 & 0 & 0 & 30 & 0 & 25 \\
\hline
\end{tabular}

BSC: Beniseed cake, SBM: soybean meal. 
Table 3. Dietary composition and calculated nutrient composition of the broiler starter and finisher diets.

\begin{tabular}{|c|c|c|c|c|c|c|c|c|}
\hline \multirow[b]{2}{*}{ Ingredients } & \multicolumn{4}{|c|}{ Starter } & \multicolumn{4}{|c|}{ Finisher } \\
\hline & $\mathrm{T} 1$ & $\mathrm{~T} 2$ & $\mathrm{~T} 3$ & $\mathrm{~T} 4$ & T1 & $\mathrm{T} 2$ & $\mathrm{~T} 3$ & $\mathrm{~T} 4$ \\
\hline & \multicolumn{8}{|c|}{$\mathrm{kg} 100 \mathrm{~kg}^{-1}$} \\
\hline Yellow maize & 45.00 & 45.00 & 45.00 & 45.00 & 55.00 & 55.00 & 55.00 & 55.00 \\
\hline SBM & 30.00 & 20.00 & 10.00 & - & 25.00 & 15.00 & 10.00 & - \\
\hline BSC & - & 10.00 & 20.00 & 30.00 & - & 10.00 & 15.00 & 25.00 \\
\hline Rice bran & 6.00 & 6.00 & 6.00 & 6.00 & 5.00 & 5.00 & 5.00 & 5.00 \\
\hline $\mathrm{PKC}$ & 5.00 & 5.00 & 5.00 & 5.00 & 4.00 & 4.00 & 4.00 & 4.00 \\
\hline Fish meal & 6.00 & 6.00 & 6.00 & 6.00 & 4.00 & 4.00 & 4.00 & 4.00 \\
\hline Blood meal & 3.00 & 3.00 & 3.00 & 3.00 & 3.00 & 3.00 & 3.00 & 3.00 \\
\hline Bone meal & 4.00 & 4.00 & 4.00 & 4.00 & 3.00 & 3.00 & 3.00 & 3.00 \\
\hline Lysine & 0.25 & 0.25 & 0.25 & 0.25 & 0.25 & 0.25 & 0.25 & 0.25 \\
\hline Methionine & 0.25 & 0.25 & 0.25 & 0.25 & 0.25 & 0.25 & 0.25 & 0.25 \\
\hline Salt & 0.25 & 0.25 & 0.25 & 0.25 & 0.25 & 0.25 & 0.25 & 0.25 \\
\hline Vitamin premix & 0.25 & 0.25 & 0.25 & 0.25 & 0.25 & 0.25 & 0.25 & 0.25 \\
\hline Total & 100.00 & 100.00 & 100.00 & 100.00 & 100.00 & 100.00 & 100.00 & 100.00 \\
\hline \multicolumn{9}{|l|}{ Calculated chemical composition: } \\
\hline Crude protein & 25.64 & 25.44 & 25.24 & 25.04 & 22.62 & 22.42 & 22.22 & 22.12 \\
\hline Ether extract & 4.66 & 5.01 & 5.36 & 5.71 & 4.43 & 4.78 & 5.13 & 5.30 \\
\hline Crude fiber & 4.56 & 4.56 & 4.56 & 4.56 & 4.25 & 4.25 & 4.25 & 4.25 \\
\hline Calcium & 1.73 & 1.91 & 2.09 & 2.29 & 1.28 & 1.46 & 1.64 & 1.73 \\
\hline Phosphorus & 1.25 & 1.34 & 1.41 & 1.46 & 1.02 & 1.09 & 1.16 & 1.20 \\
\hline Metabolizable energy, $\mathrm{MJ} \mathrm{kg}^{-1}$ & 11.72 & 11.82 & 11.92 & 12.00 & 12.16 & 12.25 & 12.35 & 12.39 \\
\hline
\end{tabular}

SBM: Soybean meal, BSC: beniseed cake, PKC: palmkernel cake.

Vitamin premix contains the following per kg feed: $5000000 \mathrm{IU}$ Vit A, $1000000 \mathrm{IU} \mathrm{Vit}_{3}, 1875 \mathrm{IU}$ Vit E, $1255 \mathrm{mg}$ Vit $\mathrm{K}, 0.6255 \mathrm{mg}$ thiamin (B $)$, $1.875 \mathrm{mg}$ riboflavin $\left(\mathrm{B}_{2}\right), 2.8 \mathrm{~kg}$ calcium pantothenate, $5.625 \mathrm{mg}$ nicotinic acid $\left(\mathrm{B}_{3}\right), 0.625 \mathrm{mg}$ pyridoxine $\left(\mathrm{B}_{6}\right), 5 \mathrm{mg}$ Vit $\mathrm{B}_{12}, 0.31 \mathrm{mg}$ folic acid, $0.1 \mathrm{mg}$ biotin, $150 \mathrm{mg}$ choline chloride, $75 \mathrm{mg}$ methionine, $5 \mathrm{mg} \mathrm{Mn}, 10 \mathrm{mg} \mathrm{Fe}, 1.5 \mathrm{mg} \mathrm{Cu}, 0.5 \mathrm{mg} \mathrm{I}, 1.0 \mathrm{mg}$ Co, $0.05 \mathrm{mg}$ Se, $50 \mathrm{mg}$ antioxidant, $7.5 \mathrm{mg}$ antimold, $10 \mathrm{mg}$ nigrovin, and $75 \mathrm{mg}$ lysine.

The pens were monitored twice daily to ascertain the health status of the chicks, and all causes of death properly recorded. After slaughtering at FBW, carcass and internal organs characteristics were measured from two birds per replicate, selected randomly. The external parts (heads, necks, wings and legs) were expressed as proportion of their body weight in percentages while the internal organs were carefully removed and weighed to determine their fresh weights.

European performance efficiency factor (EPEF) was calculated at FBW as follows:

$$
E P E F=\frac{(B W \times L V)}{F C R+D O M} \times 100
$$

where $B W$ is body weight $(\mathrm{kg}), L V$ is liveability (\%), $F C R$ is feed conversion ratio, and DOM is age of birds (d) up to marketing.

Blood samples were collected from randomly selected birds per replicate for hematological and biochemical indices. Sterile syringes were used to collect blood into sterile bottles containing anti-coagulant (ethylenediaminetetraacetic acid, EDTA) for hematological indices, and into sterile bottles without anti-coagulants for serum biochemical indices. The EDTA blood samples were analyzed for red blood cells (RBC), packed cell volume (PCV), hemoglobin ( $\mathrm{Hb})$, and white blood cells (WBC), while the coagulated blood samples were subjected to standard serum separation for total protein, globulin, albumin, urea, creatinine and cholesterol. The mean corpuscular volume (MCV), mean corpuscular hemoglobin $(\mathrm{MCH})$, and mean corpuscular hemoglobin concentration (MCHC) were determined according to Sirois (1995).

\section{Statistical analysis}

Data were analyzed using ANOVA for a complete randomized design according to SAS (SAS Institute, 2010). Treatment means were separated using Fisher's protected t-test least significant difference (LSD) at 5\% level of significance. Growth, carcass and blood indices significantly affected by substitution levels of white BSC for SBM were modelled using the following quadratic function:

$$
Y=a+b 1 x+b 2 x^{2}+e
$$

where $Y$ is growth, carcass and blood indices of cobb broilers; $a$ is intercept on Y-axis; $b$ is coefficients of the independent variable $x$, which is the inclusion levels of BSC estimated as $-\mathrm{b} 1 / 2 \mathrm{~b} 2$; that gives the optimum inclusion level. The quadratic model was fitted to the experimental data by means of the non-linear model (NLIN) procedure of SPSS (SPSS, 2017). The quadratic model was used because it gave the best fit.

\section{RESULTS}

The 100\% substitution of BSC for SBM was significantly lowest compared to other treatments for BW28, FBW and ADFI (Table 4). However, ADWG, FCR and mortality were nonsignificantly affected by any level of substitution of BSC for SBM.

The EPEF shows that $100 \%$ substitution of BSC was significantly highest in efficiency, while $0 \%$ substitution was least efficient, with $25 \%$ and $75 \%$ nonsignificantly different from $100 \%$ substitution of BSC. Chickens fed $0 \%, 25 \%$ and $75 \%$ BSC were significantly highest for dressing percentage, and carcass weight than $100 \%$ BSC 
Table 4. Effect of dietary substitution levels of soybean meal (SBM) for beniseed cake (BSC) on the performance of broilers.

\begin{tabular}{|c|c|c|c|c|c|c|}
\hline \multirow[b]{4}{*}{ Parameters } & \multicolumn{4}{|c|}{ Replacement levels of SBM with BSC } & \multirow[b]{4}{*}{ SEM } & \multirow[b]{4}{*}{ P-value } \\
\hline & $\mathrm{T} 1$ & $\mathrm{~T} 2$ & $\mathrm{~T} 3$ & $\mathrm{~T} 4$ & & \\
\hline & $\begin{array}{c}(100 \% \text { SBM } \\
+0 \% \text { BSC })\end{array}$ & $\begin{array}{c}(75 \% \text { SBM } \\
+25 \% \text { BSC) }\end{array}$ & $\begin{array}{c}(25 \% \text { SBM } \\
+75 \% \text { BSC) }\end{array}$ & $\begin{aligned} & (0 \% \text { SBM } \\
+ & 100 \% \text { BSC })\end{aligned}$ & & \\
\hline & $\mathrm{n}=66$ & $\mathrm{n}=66$ & $\mathrm{n}=66$ & $\mathrm{n}=66$ & & \\
\hline IBW, $\mathrm{g} \mathrm{bird}^{-1}$ & 42.00 & 43.00 & 42.50 & 43.00 & 0.239 & 0.965 \\
\hline BW at $28 \mathrm{~d}, \mathrm{~g} \mathrm{bird}^{-1}$ & $825.00 \mathrm{a}$ & $873.00 \mathrm{a}$ & $817.00 \mathrm{a}$ & $694.00 \mathrm{~b}$ & 38.14 & 0.064 \\
\hline FBW at $56 \mathrm{~d}, \mathrm{~g} \mathrm{bird}^{-1}$ & $2347.00 \mathrm{a}$ & $2422.00 \mathrm{a}$ & $2336.00 \mathrm{a}$ & $2295.00 \mathrm{~b}$ & 26.48 & 0.059 \\
\hline ADWG, $\mathrm{g} \mathrm{bird}^{-1}$ & 41.80 & 43.20 & 41.60 & 40.90 & 0.46 & 0.876 \\
\hline ADFI, g bird ${ }^{-1}$ & $103.40 \mathrm{a}$ & $108.70 \mathrm{a}$ & $100.80 \mathrm{a}$ & $86.40 \mathrm{~b}$ & 4.77 & 0.052 \\
\hline FCR & 2.47 & 2.52 & 2.42 & 2.11 & 0.10 & 0.541 \\
\hline EPEF & $159.40 \mathrm{~b}$ & $171.63 \mathrm{ab}$ & $172.37 \mathrm{ab}$ & $194.23 \mathrm{a}$ & 5.28 & 0.062 \\
\hline DP, $\%$ & $63.93 \mathrm{ab}$ & $75.26 \mathrm{a}$ & $59.22 \mathrm{~b}$ & $60.11 \mathrm{ab}$ & 3.96 & 0.051 \\
\hline $\mathrm{CW}, \mathrm{g}$ & $2060.05 \mathrm{ab}$ & $2135.00 \mathrm{a}$ & $2040.00 \mathrm{ab}$ & $2000.05 b$ & 46.83 & 0.056 \\
\hline Mortality, nr & 2.00 & 0.00 & 0.00 & 0.00 & 0.447 & 0.997 \\
\hline $\mathrm{FC}, \mathrm{US} \$ \mathrm{~kg}^{-1}$ & 0.51 & 0.43 & 0.36 & 0.32 & & \\
\hline $\mathrm{FC} / \mathrm{kg}$ gain, US $\$ \mathrm{~kg}^{-1}$ & 1.28 & 1.12 & 0.90 & 0.76 & & \\
\hline
\end{tabular}

IBW: Initial body weight, BW: body weight, FBW: final body weight, ADWG: average daily weight gain, ADFI: average daily feed intake, FCR: feed conversion ratio, EPEF: European performance efficiency factor i.e. liveability $(\%) \times$ live weight $(\mathrm{kg}) \times$ age $(\mathrm{d}) / \mathrm{FCR} \times 100$; DP: dressing percentage, CW: carcass weight, FC: feed cost, SEM: standard error of the mean.

Means with different lower-case letters within the same row differ significantly $(\mathrm{p}<0.05)$.

substitution. The feed cost and feed cost per kilogram gain showed that feed cost decreased as the substitution level of BSC for SBM increased.

Among the carcass, external and internal organ weights, only the abdominal fat was significantly influenced by $25 \%$, $75 \%$ and $100 \%$ substitution of BSC for SBM, with $0 \%$ substitution being significantly different (Table 5). The rest of the parameters were nonsignificantly influenced by the substitution levels of BSC for SBM.

The effect of substitution of BSC for SBM on hematological and biochemical indices shows that only WBC was influenced for hematological indices, while protein and urea were influenced for serum biochemical indices (Table 6). The 25\%, $75 \%$ and $100 \%$ substitution levels were significantly highest for WBC than $0 \%$ substitution. Also, $0 \%$ substitution was significantly highest for protein and urea than the other treatments, although $100 \%$ substitution was nonsignificantly different from $0 \%$ for protein.

Among the significant parameters, only ADFI, carcass weight, abdominal fat, WBC, protein and urea could fit into the quadratic function model, while BW28, FBW, EPEF and DP could not fit. ADFI showed a significant $(\mathrm{P}<0.05)$ quadratic function with a high $\mathrm{R}^{2}$ value of $99.2 \%$, with optimal substitution level of 22.5\% BSC and 77.5\% SBM (Table 7).

The optimal substitution levels of BSM for SBM based on the quadratic function are $22.5 \% \mathrm{BSC}$ and $77.5 \% \mathrm{SBM}$ for $\mathrm{ADFI}, 25 \% \mathrm{BSC}$ and $75 \% \mathrm{SBM}$ for carcass weight, $60 \% \mathrm{BSC}$ and $40 \% \mathrm{SBM}$ for protein, $75 \% \mathrm{BSC}$ and $25 \% \mathrm{SBM}$ for abdominal fat, $80 \% \mathrm{BSC}$ and $20 \% \mathrm{SBM}$ for $\mathrm{WBC}$ and $95 \% \mathrm{BSC}$ and 5\%SBM for urea. However, only ADFI was significant for the quadratic function, the rest were not.

Table 5. Effect of dietary substitution levels of soybean meal (SBM) for beniseed cake (BSC) on external, internal body parts and organ weights.

\begin{tabular}{|c|c|c|c|c|c|c|}
\hline \multirow[b]{2}{*}{ Parameters } & \multicolumn{4}{|c|}{ SBM Replacement levels } & \multirow[b]{2}{*}{ SEM } & \multirow[b]{2}{*}{ P-value } \\
\hline & $\begin{array}{c}\mathrm{T} 1 \\
(100 \% \mathrm{SBM} \\
+0 \% \mathrm{BSC})\end{array}$ & $\begin{array}{c}\mathrm{T} 2 \\
(75 \% \mathrm{SBM} \\
+25 \% \mathrm{BSC})\end{array}$ & $\begin{array}{c}\mathrm{T} 3 \\
(25 \% \mathrm{SBM} \\
+75 \% \mathrm{BSC})\end{array}$ & $\begin{array}{c}\mathrm{T} 4 \\
(0 \% \mathrm{SBM} \\
+100 \% \mathrm{BSC})\end{array}$ & & \\
\hline Head, \% & 2.46 & 2.47 & 2.35 & 2.46 & 0.028 & 0.971 \\
\hline Shank, \% & 3.55 & 3.37 & 2.99 & 3.83 & 0.175 & 0.432 \\
\hline Neck, \% & 4.14 & 4.32 & 4.33 & 4.43 & 0.060 & 0.658 \\
\hline Drumstick, \% & 10.05 & 10.36 & 9.63 & 10.00 & 0.149 & 0.125 \\
\hline Tip of wings, $\%$ & 1.04 & 1.05 & 0.96 & 1.15 & 0.039 & 0.542 \\
\hline \multicolumn{7}{|l|}{ Internal organ weights } \\
\hline Heart weight, g & 0.49 & 0.47 & 0.53 & 0.38 & 0.031 & 0.812 \\
\hline Lungs weight, g & 0.64 & 0.69 & 0.69 & 0.61 & 0.019 & 0.654 \\
\hline Kidney weight, g & 0.01 & 0.02 & 0.01 & 0.02 & 0.002 & 0.504 \\
\hline Pancreas weight, $g$ & 0.15 & 0.17 & 0.14 & 0.12 & 0.010 & 0.651 \\
\hline Intestine, $\mathrm{g}$ & 5.19 & 5.26 & 4.81 & 4.92 & 0.107 & 0.551 \\
\hline Abdominal fat, $g$ & $1.09 \mathrm{~b}$ & $2.05 \mathrm{a}$ & $2.19 \mathrm{a}$ & $1.97 \mathrm{a}$ & 0.249 & 0.052 \\
\hline Liver plus gall bladder, g & 2.24 & 2.05 & 2.94 & 2.02 & 0.214 & 0.092 \\
\hline Gizzard full, g & 3.06 & 3.16 & 2.51 & 3.44 & 0.194 & 0.176 \\
\hline
\end{tabular}

Means with different lower-case letters within the same row differ significantly $(\mathrm{p}<0.05)$.

SEM: Standard error of the mean. 
Table 6. Effect of dietary substitution levels of soybean meal (SBM) for beniseed cake (BSC) on hematology and biochemical indices.

\begin{tabular}{|c|c|c|c|c|c|c|}
\hline \multirow[b]{2}{*}{ Parameters* } & \multicolumn{4}{|c|}{ SBM substitution levels } & \multirow[b]{2}{*}{ SEM } & \multirow[b]{2}{*}{ P-value } \\
\hline & $\begin{array}{c}\mathrm{T} 1 \\
(100 \% \mathrm{SBM} \\
+0 \% \mathrm{BSC}) \\
\end{array}$ & $\begin{array}{c}\mathrm{T} 2 \\
(75 \% \text { SBM } \\
+25 \% \text { BSC) } \\
\end{array}$ & $\begin{array}{c}\mathrm{T} 3 \\
(25 \% \text { SBM } \\
+75 \% \text { BSC) } \\
\end{array}$ & $\begin{array}{c}\mathrm{T} 4 \\
(0 \% \mathrm{SBM} \\
+100 \% \mathrm{BSC})\end{array}$ & & \\
\hline $\mathrm{Hb}, \mathrm{g} \mathrm{dL}^{-1}$ & 11.13 & 10.80 & 11.83 & 11.60 & 0.231 & 0.877 \\
\hline $\operatorname{RBC}\left(\times 10^{12} \mathrm{~L}^{-1}\right)$ & 2.86 & 2.18 & 2.92 & 2.94 & 0.182 & 0.654 \\
\hline WBC $\left(\times 10^{9} \mathrm{~L}^{-1}\right)$ & $106.00 \mathrm{~b}$ & $114.16 \mathrm{a}$ & $114.20 \mathrm{a}$ & $115.16 \mathrm{a}$ & 2.139 & 0.026 \\
\hline $\mathrm{PCV}, \%$ & 24.72 & 25.53 & 26.70 & 26.06 & 0.419 & 0.567 \\
\hline $\mathrm{MCV}, \mathrm{fL}$ & 121.33 & 123.33 & 123.67 & 123.33 & 0.534 & 0.127 \\
\hline $\mathrm{MCH}, \mathrm{pg}$ & 45.10 & 45.20 & 47.33 & 44.90 & 0.569 & 0.976 \\
\hline $\mathrm{MCHC}, \%$ & 38.46 & 37.80 & 39.06 & 37.16 & 0.410 & 0.762 \\
\hline Monocytes, \% & 7.16 & 6.26 & 5.63 & 5.26 & 0.415 & 0.231 \\
\hline Neutrophils, \% & 20.61 & 21.28 & 17.38 & 17.29 & 1.051 & 0.620 \\
\hline Lymphocytes, \% & 80.06 & 78.56 & 79.03 & 77.34 & 0.564 & 0.790 \\
\hline \multicolumn{7}{|l|}{ Biochemical indices } \\
\hline Protein, $\mathrm{Mg} \mathrm{dL}^{-1}$ & $35.00 \mathrm{a}$ & $29.63 b$ & $29.83 b$ & $28.33 b$ & 1.260 & 0.061 \\
\hline Albumin, $\mathrm{g} \mathrm{dL}^{-1}$ & 20.35 & 17.43 & 17.29 & 16.90 & 0.792 & 0.304 \\
\hline Cholesterol, $\mathrm{Mg} \mathrm{dL}^{-1}$ & 134.71 & 136.71 & 132.95 & 126.80 & 2.140 & 0.621 \\
\hline Creatinine, $\mu \mathrm{mol} \mathrm{L}-1$ & 79.68 & 63.08 & 50.18 & 45.16 & 7.705 & 0.452 \\
\hline Urea, $\mathrm{Mmol} \mathrm{L}^{-1}$ & $2.16 \mathrm{a}$ & $1.88 \mathrm{~b}$ & $1.28 \mathrm{~b}$ & $1.32 \mathrm{~b}$ & 0.248 & 0.047 \\
\hline Glucose, $\mathrm{Mmol} \mathrm{L}^{-1}$ & 10.23 & 10.48 & 11.69 & 12.60 & 0.551 & 0.782 \\
\hline
\end{tabular}

Means with different lower-case letters within the same row differ significantly $(\mathrm{p}<0.05)$.

SEM: Standard error of mean, P-value: probability value, Hb: hemoglobin count, RBC: red blood cell count, WBC: white blood cell count, PCV: packed cell volume, MCV: mean corpuscular volume, MCH: mean corpuscular hemoglobin, MCHC: mean corpuscular hemoglobin concentration.

Table 7. Optimal substitution of beniseed cake (BSC) for soybean meal (SBM) on growth, carcass and blood characteristics of Cobb broilers using quadratic function.

\begin{tabular}{|c|c|c|c|c|}
\hline Trait & Quadratic function & $\begin{array}{l}\text { Optimal \% } \\
\text { BSC+SBM }\end{array}$ & $\mathrm{R}^{2}$ Value & Probability values \\
\hline ADFI, g & $Y=89.93+18.74 x-4.93 x^{2}$ & 1.90 & 0.992 & 0.051 \\
\hline Carcass weight, g & $Y=1983.90+116.125 x-28.73 x^{2}$ & 2.02 & 0.737 & 0.513 \\
\hline Abdominal fat, $\mathrm{g}$ & $Y=-0.345+1.75 x-0.295 x^{2}$ & 2.97 & 0.986 & 0.103 \\
\hline WBC & $Y=96+12.292 x-1.90 x^{2}$ & 3.23 & 0.946 & 0.233 \\
\hline Protein & $Y=43.49-10.619 x+1.968 x^{2}$ & 2.70 & 0.972 & 0.167 \\
\hline Urea & $Y=3.09-0.982 x+0.13 x^{2}$ & 3.78 & 0.836 & 0.405 \\
\hline
\end{tabular}

ADFI: Average daily feed intake, WBC: white blood cell count.

\section{DISCUSSION}

The low BW28, FBW and ADFI when BSC is replaced $100 \%$ for SBM may be due to its un-palatable, fibrous and oily nature resulting in reduced feed intake. This is similar to findings by Phosa (2009) and van Ryssen et al. (2014) that chickens feed $100 \%$ macadamia oil cake meal exhibited depressed feed intake and retarded growth, which was ascribed to high fiber content of the meal. Meanwhile the general trend in previous BSC studies revealed that layer hens tolerated higher levels of BSC (Tangtaweewipat and Cheva-Isarakul, 1993; Mamputu and Buhr, 1995), without adversely deviating from their control groups' counterparts, while broilers fed BSC above $7.5 \%$ experienced reduced feed intake, BWG, and feed conversion during the first 3 wk of age. Also Rahimian et al. (2013) reported a lower body weight and feed conversion efficiency when increasing levels of BSC were introduced in broiler starter, grower and finisher diets. However, this is in contrast to the findings of Baghel and Netke (1987) that inferred that a combination of $23.5 \%$ soybean meal extraction and $28.2 \%$ sesame meal as a protein supplement in broiler ration was economical and gave maximum performance in broilers; while Acheampong-Boateng et al. (2016) concluded that macadamia oil cake meal at $25 \%$ inclusion level can improve performance of broiler chickens.

Some reports (Mamputu and Buhr, 1995; Kaneko et al., 2002) also indicated a depressed performance in broilers when BSC totally replaced SBM. The wide variation in results observed in literature on utilization of BSC in chicken diet may be due to variability in processing temperature during oil extraction from seeds (Mamputu and Buhr, 1995; Rao et al., 2008). However, this study has shown the positive ability of Cobb broilers to utilize white BSC up to $75 \%$ substitution for SBM based on improved BW28, FBW, ADWG, ADFI, EPEF and CW. Mamputu and Buhr (1995) opined that the processing method for oil extraction (screw press or solvent extraction) and temperature used for roasting the seed might have altered the availability of the basic amino acids and in turn affected the feeding value of BSC for poultry. However, white BSC in this experiment might be different due to its variety, which may also have accounted for its utilization up to $75 \%$ in Cobb broiler diets. In the same vein, the EPEF values reported in this experiment shows a substantial level in relation to other findings. Samarakoon and Samarasinghe 
(2012) reported that EPEF provides a reasonable idea about the overall technical efficiency of broiler operations, and the highest value gives the optimum return. With significant differences observed for the treatments in this study, values for diets high in BSC (25\%-100\% substitution) proved to have the maximum returns compared to diets low in BSC ( $0 \%$ substitution). The values of EPEF reported are closely related to previous studies (Petek et al., 2005; Awad et al., 2009; Acheampong-Boateng et al., 2016). A possible explanation for high EPEF values for high levels of BSC to $\mathrm{SBM}$ ratio might be due to the protein quality of diets offered, as broilers consuming diets with higher proportion of BSC were able to utilize the protein more efficiently to grow faster, compared to broilers on diets with the same level of SBM.

The effect of substitution of BSC on external, internal body parts and organ weights shows abdominal fat being the only significantly affected parameter. The high abdominal fat is shown on broilers fed between $25 \%-100 \%$ BSC. This may be due to high levels of fat in BSC compared to SBM, which is about twice the amount of energy compared to carbohydrates. Since broilers primarily consume feed in order to satisfy their energy needs, the excess energy will be converted to fat which act as energy reserves for the chickens (Fouad and El-Senousey, 2014). Although the excessive fat deposition is an unfavorable trait in broiler industry, its organoleptic effects on the flavor of the meat is favorable. However, not every consumer appreciates this quality as it affects the carcass quality (Emmerson, 1997).

The effect of substitution of BSC on hematological and biochemical parameters shows a significant effect on WBC, serum protein and urea. The PCV and $\mathrm{HB}$ are correlated with the nutritional status of the animal (Adejumo, 2004). $\mathrm{HB}$ is usually transported in the RBC, and RBC together with WBC constitutes the major part of blood in animals, which helps to determine the health status of animals. The values reported in this study are similar to the values reported by Banerjee (1998) and Yakubu and Alfred (2014). A highly significant value of WBC with increased levels of BSC substitution (25\%-100\% substitution) may be due to increased secretion of cells in the blood due to increased levels of anti-nutritional factors (phytate) found in the BSC based diets. The total serum protein and albumin are indicators of the total serum protein reserve in an animal body (Bamgbose et al., 2003). The adequacy of protein content in chicken is influenced by the values for creatinine (Table 6), there is nonsignificant change, but numerically; as the level of substitution increases, the creatinine levels becomes lower. This could be due to high level of phytate in BSC-based diets which might have reduced protein digestibility (Hossain and Jauncey, 1989), and is evident from the progressive and significant reduction in serum protein concentration with an increase in the proportion of BSC in the diet. Banerjee (1998) in his study on sources and types of protein observed significant variations in serum creatinine and uric acid on broilers fed varying levels of sesame meal. Yamauchi et al. (2006) reported that sesame meal inhibits cholesterol absorption from the intestine and synthesis in the liver.

The results of the present study indicate that dietary optimal BSC substitution levels for SBM of $22.5 \% \mathrm{BSC}+77.5 \% \mathrm{SBM}, 25 \% \mathrm{BSC}+75 \% \mathrm{SBM}$, $60 \%$ B S C + $40 \%$ S B M , $75 \%$ B S C + 25\% S B M, $80 \% \mathrm{BSC}+20 \% \mathrm{SBM}$, and $95 \% \mathrm{BSC}+5 \% \mathrm{SBM}$ supported optimum ADFI, carcass weight, serum protein, abdominal fat, WBC and serum urea, respectively, with probability values ranging from 0.051 to 0.513 . A significant average daily feed intake (ADFI) was achieved at an optimum BSC substitution level for SBM of $22.5 \% \mathrm{BSC}+77.5 \%$ $\mathrm{SBM}$ with $\mathrm{Y}=89.93+18.74 \mathrm{x}-4.93 \mathrm{x}^{2}, \mathrm{R}^{2}=0.992$, $P$-value of 0.051 . Several studies had applied the quadratic regression model to optimize inclusion levels of feed and other materials on chicken (Mbajiorgu, 2011; Mbajiorgu et al., 2011; Alabi et al., 2015; Okoro et al., 2016; 2017). However, none of these studies has reported on optimizing the effect of substitution levels of BSC for SBM on growth, carcass and blood characteristics of Cobb broilers. Thus, this study which aligns with previous studies in chickens on the optimum dose response values of dietary nutrient inclusion levels for optimizing different parameters have been dynamic, but trials in which parametric performances were achieved at variable optimal dietary nutrient inclusion levels predominate.

In this study, only ADFI was significantly influenced by the chosen optimization model. This suggests that the substitution level reported could ensure adequate daily feed intake, hence could support high productive efficiency in Cobb broilers. Importantly, a sharp increase in ADFI above this optimum BSC substitution (Figure 1) tended to indicate that adequate feed intake will be affected by this slight increase in BSC substitution and could probably be attributed to low growth performance due to the test ingredient as the level of supplementation increases. Thus, it is clear from the results herein that BSC substitution for SBM above $25 \%$ in the diet of Cobb broilers will decrease average daily feed intake and will have important consequences on the performance and growth of Cobb

Figure 1. Effect of optimum substitution of beniseed cake (BSC) for soybean meal (SBM) on average daily feed intake (ADFI).

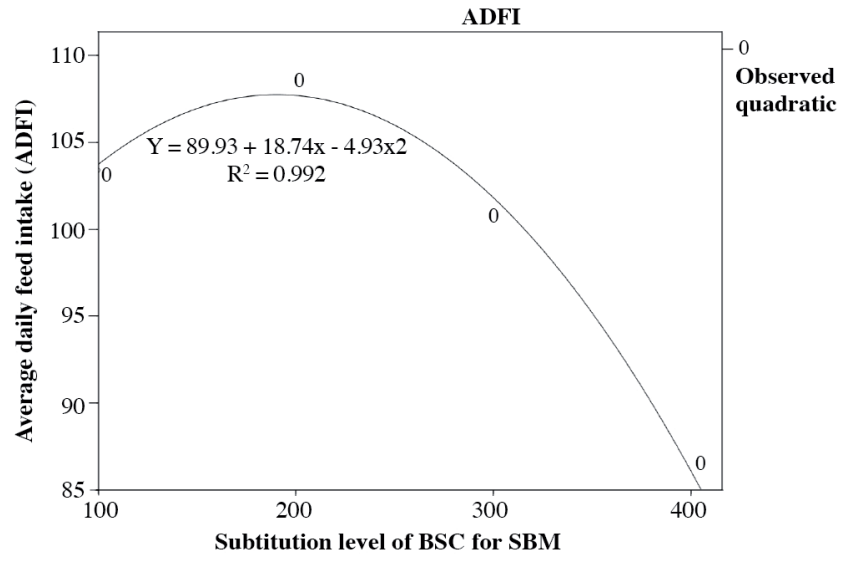


broilers. These findings have many implications on the substitution of BSC for SBM to enhance growth carcass and blood characteristics of Cobb broilers.

\section{CONCLUSIONS}

This study has shown that the Nigerian white beniseed cake could have positive effects on the growth, carcass and blood characteristics of broilers. In this study, there is a significant effect on the performance of Cobb broilers in terms of body weight at $28 \mathrm{~d}$, final body weight at $56 \mathrm{~d}$, average daily weight gain, average daily feed intake, and carcass weight at substitution levels of $25 \%$ and $75 \%$ for soybean meal. This finding which is not similar to most others carried out elsewhere using different varieties of beniseed cake is significant. Also, the optimum substitution level influences only average daily feed intake at $22.5 \%$ beniseed cake and $77.5 \%$ soybean meal, which is within the range reported earlier by some authors. Therefore, substituting soybean meal up to $75 \%$ with Nigerian white beniseed cake does not have adverse effects on broiler chicken reared to $56 \mathrm{~d}$, rather improves their performance.

\section{ACKNOWLEDGEMENTS}

The authors are grateful to the Federal University of Technology, Owerri, for the Postgraduate scholarship grant for this research, carried out by Mr. Akwukwuegbu Simon (grant nr 2013/07/3B).

\section{REFERENCES}

Acheampong-Boateng, O., Bakare, A., and Mbatha, K. 2016. The potential of replacing soybean oil cake with macadamia oil cake in broiler diets. Tropical Animal Health and Production 48:1283-1286.

Adejumo, D. 2004. Performance, organ development and hematological indices of rats fed sole diets of graded levels of cassava flour and soybean flour (soygari) as substitutes for energy and protein concentrates. Tropical Journal of Animal Science 7:57-63.

Agbulu, O., Gyau, A., and Abakura, J. 2010. Effect of the replacement of sesame seed for methionine in broiler production in middle belt region-Nigeria. Journal of Emerging Trends in Educational Research and Policy Studies 1:16-21.

Alabi, O., Ng'ambi, J., Mbajiorgu, E., Norris, D., and Mabelebele, M. 2015. Growth and haematological response of indigenous Venda chickens aged 8 to 13 weeks to varying dietary lysine to energy ratios. Journal of Animal Physiology and Animal Nutrition 99:436-441.

AOAC. 1995. Official methods of chemical analysis. Association of Official Analytical Chemists (AOAC), Arlington, Virginia, USA.

Awad, W., Ghareeb, K., Abdel-Raheem, S., and Bohm, J. 2009. Effects of dietary inclusion of probiotic and synbiotic on growth performance, organ weights, and intestinal histomorphology of broiler chickens. Poultry Science 88:49-56.

Baghel, R., and Netke, S. 1987. Economic broiler ration based on vegetable proteins. Indian Journal of Animal Nutrition 4:24-27.
Bamgbose, A., Nwokoro, S., and Tewe, O. 2003. Serum metabolites and nutrient utilization of boilers fed extruded full fat soya bean diets. Journal of Arid Agriculture 13:167-171.

Banerjee, G. 1998. Feeds and principles of animal nutrition. Revised edition. Oxford \& IBH Publishing, New Delhi, India.

Diarra, S., and Usman, B. 2008. Performance of laying hens fed graded levels of soaked sesame (Sesamum indicum) seed meal as a source of methionine. International Journal of Poultry Science 7:323-327.

Emmerson, D. 1997. Commercial approaches to genetic selection for growth and feed conversion in domestic poultry. Poultry Science 76:1121-1125.

Farran, M., Uwayjan, M., Miski, A., Akhdar, N., and Ashkarian, V. 2000. Performance of broilers and layers fed graded levels of sesame hull. Journal of Applied Poultry Research 9:453-459.

Fouad, A., and El-Senousey, H. 2014. Nutritional factors affecting abdominal fat deposition in poultry: a review. AsianAustralasian Journal of Animal Science 27:1057-1068.

Hossain, M., and Jauncey, K. 1989. Nutritional evaluation of some Bangladeshi oilseed meals as partial substitutes for fish meal in the diet of common carp, Cyprinus carpio L. Aquaculture Research 20:255-268.

Kaneko, K., Yamasaki, K., Tagawa, Y., Tokunaga, M., Tobisa, M., and Furuse, M. 2002. Effects of dietary sesame meal on growth, meat ingredient and lipid accumulation in broilers. Journal of Poultry Science 39:56-62.

Langham, D. 2007. Phenology of sesame. Reprinted from issues in new crops and new uses. 2007. 120-132 p. Janick, J., and Whipkey, A. (eds.) ASHS Press, Alexandria, Virginia, USA.

Mahmoud, K.Z., Obeidat, B.S., and Ishmais, M.A. 2015. Roasted sesame hulls improve broiler performance without affecting carcass characteristics. Italian Journal of Animal Science 14:495-501.

Mamputu, M., and Buhr, R. 1995. Effect of substituting sesame meal for soybean meal on layer and broiler performance. Poultry Science 74:627-684.

Mbajiorgu, C. 2011. The response of male indigenous Venda chickens to diet energy to protein ratios fed from seven up to 13 weeks of age. Journal of Human Ecology 35:161-165.

Mbajiorgu, C., Ng`ambi, J., Norris, D., and Alabi, O. 2011. Effect of dietary lysine to energy ratio on performance of unsexed indigenous Venda chickens. Asian Journal of Animal and Veterinary Advances 6:517-524.

Mengesha, M. 2012. Feed resources and chicken production in Ethiopia. Worlds Poultry Science Journal 68:491-501.

Okoro, V., Mbajiorgu, C., and Mbajiorgu, E. 2016. Semen quality characteristics of Koekoek breeder cocks influenced by supplemental inclusion levels of onion and garlic mixture at 3541 weeks of age. Revista Brasileira de Zootecnia 45:433-440.

Okoro, V., Ravhuhali, K., Mapholi, T., Mbajiorgu, E., and Mbajiorgu, C. 2017. Effect of age on production characteristics of Boschveld indigenous chickens of South Africa reared intensively. South African Journal of Animal Science 47:157-167.

Oluyemi, J., and Roberts, F. 2000. Poultry production in warm wet climates. $2^{\text {nd }}$ ed. Macmillan Press, London, UK.

Petek, M., Sönmez, G., Yildiz, H., and Baspinar, H. 2005. Effects of different management factors on broiler performance and incidence of tibial dyschondroplasia. British Poultry Science 46:16-21.

Phosa, M. 2009. The nutritive value of macadamia oil cake meal and wood ash as alternative feed ingredients for chickens in rural areas. University of Pretoria, Pretoria, South Africa. 
Rahimian, Y., Tabatabaie, S., Valiollahi, S., Toghiani, M., Kheiri, F., Zamani, F., et al. 2013. Effect of use cumulative levels of sesame (Sesamum indicum) meal with phytase enzyme on performance of broiler chicks. Scientific Journal of Veterinary Advances 2:178-188.

Rao, S.R., Raju, M., and Panda, A. 2008. Utilisation of sesame (Sesamum indicum) seed meal in broiler chicken diets. British Poultry Science 49:81-85.

van Ryssen, J., Phosa, M., and van Rensburg, C. 2014. Different levels of macadamia oil cake meal, and wood ash vs. feed lime as dietary sources of calcium on bone characteristics of slowgrowing chickens. South African Journal of Animal Science 44:71-79.

Samarakoon, S., and Samarasinghe, K. 2012. Strategies to improve the cost effectiveness of broiler production. Tropical Agricultural Research 23:338-346.

SAS Institute. 2010. SAS/STAT 9.3 User's guide survey data analysis. Page Statistical Analysis Software User's Guide. SAS Institute, Cary, North Carolina, USA.
Sirois, M. 1995. Veterinary clinical laboratory procedures. p. 2367. Mosby Year Book, St Louis, Missouri, USA.

SPSS. 2017. IBM SPSS statistics software 24. IBM, Armonk, New York, USA. Available at http://www.spss.com (accessed 16 May 2017).

Tangtaweewipat, S., and Cheva-Isarakul, B. 1993. Sesame meal as soybean meal substitute in poultry diets. Asian-Australasian Journal of Animal Science 6:253-258.

Yakubu, B., and Alfred, B. 2014. Nutritional evaluation of toasted white sesame seed meal Sesamum indicum as a source of methionine on growth performance, carcass characteristics. IOSR Journal of Agriculture and Veterinary Science 7:46-52.

Yamauchi, K., Samanya, M., Seki, K., Ijiri, N., and Thongwittaya, N. 2006. Influence of dietary sesame meal level on histological alterations of the intestinal mucosa and growth performance of chickens. Journal of Applied Poultry Research 15:266-273. 